\author{
Alexandria Journal of Veterinary Sciences 2014, 42: 59-63 \\ ISSN 1110-2047, www.alexjvs.com \\ DOI: 10.5455/ajvs.151300
}

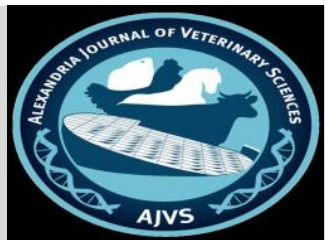

\title{
Effect of Certain Immunomodulators on Uterine Microbiology in Cyclic Non Breeding Cows
}

\author{
Saraswat Sahoo ${ }^{1}$, Debendra. N. Mohanty ${ }^{1}$, Srinibas Das ${ }^{2}$ and Arpita Padhy ${ }^{3}$ \\ ${ }^{1}$ Department of Animal Reproduction, Gynaecology and Obstetrics, ${ }^{2}$ Teaching Veterinary Clinical Complex, \\ ${ }^{3}$ Department of Veterinary Microbiology, College of Veterinary Science and Animal Husbandry, OUAT, Bhubaneswar, \\ India \\ **Part of MVSc thesis of Saraswat Sahoo
}

\begin{tabular}{ll}
\hline Key words & ABSTRACT: \\
$\begin{array}{l}\text { Immunomodulators, } \\
\text { uterine }\end{array}$ & $\begin{array}{l}\text { A total number of twenty one repeat breeding cows selected after meticulous screening } \\
\text { based on Whiteside test and Laing's criteria then allotted randomly into three equal groups } \\
\text { microbiology, }\end{array}$ \\
Cow & $\begin{array}{l}\mathrm{n}=7) \text {. Cows in control group were lavaged with intra-uterine with } 50 \mathrm{ml} \text { of normal saline, } \\
\text { in group I } 20 \mathrm{ml} \text { of fresh colostrum and in group II infusion with } 10 \mathrm{ml} \text { of non-pathogenic } \\
\text { E.Coli in sterile saline as intra uterine medication were given. Bacterial isolates were } \\
\text { collected in pre-treatment stage (day0) and post treatment stage (day 21) and their } \\
\text { concentrations (cfu/ml) were compared.In the pre treatment stage, the predominant bacterial } \\
\text { flora and their frequency in animals constituted Klebsiella spp, Staphylococcus spp, E.coli } \\
\text { Enterococcus fecalis, Streptococcus spp, Proteus spp and Bacillus spp. In the post } \\
\text { treatment sampling after twenty one days, following different drug treatments revealed } \\
\text { inhibition of many bacterial isolates which were identified in the pre-treatment period. } \\
\text { Klebsiella spp. was found only in normal saline group whereas it was absent in colostrum } \\
\text { and E.coli treated group. Similarly Staphylococcus spp. was identified from a single case in } \\
\text { colostrum treated group whereas the other two treatment regimen did not reveal their } \\
\text { presence. Similar bacterial inhibition against Staphylococcus spp. was marked in normal } \\
\text { saline and E.coli. The presence of non pathogenic E.coli was evident in all the treatment } \\
\text { groups at post treatment period, indicating either their reinfection or due to its natural } \\
\text { presence in the reproductive tract. The cows in control group projected a first insemination } \\
\text { conception rate of 42.86\%, in group - I recorded a pregnancy rate of 57.14\% and in group - } \\
\text { II three cows became pregnant (42.86\%) out of seven inseminations. }\end{array}$ \\
\hline Corresponding Author: S. Sahoo, email- saraswat.vet06@gmail.com
\end{tabular}

\section{INTRODUCTION}

In the recent past, the incidence of infertility becomes relatively increased with consequent reduction of productivity of farm animals. Economy of dairy farming, largely depends on pregnancy rate after insemination. But, one of the major constraints of profitable dairy farming is low conception rate. Hence, the twelve month calving interval is advantageous for maximum milk yield/cow/year with good economic return. It is accepted that bovine genital infection either specific or non specific in nature, accounts for large number of pregnancy failure in cows as mentioned by Le blanc et al (2002) and ElKhadrawy et al (2012)

Generally, non specific infection of the genitalia is considered to be the main cause of repeated conception failure, where there is increase in number of microorganisms and/or in their virulence described by Azawi (2008). These infections alter the uterine environment resulting in impairment of sperm transport, sperm death and hostile environment to the subsequent development and maintenance of conceptus, leading to their death, there by affecting their fertility. It has also been reported that, severity of uterine bacterial contamination as determined by bacterial growth density. The present treatment protocol involves, use of antibiotics for combating the microbial infection of uterus, which in due course, can lead to development of bacterial resistance, minimizing the cost of treatment and diminishing uterine defense mechanism. Hence, an alternative therapy such as intra-uterine defense stimulator, has been tried in confirmed case of repeat breeding associated with bacterial endometritis which is in agreement with the findings of Singh et al (2000). 


\section{MATERIALS AND METHODS}

After proper restraining of animal, the perineum, tail and external genitalia were cleaned thoroughly with water and wiped out neatly with a piece of cotton for drying. Uterine samples were collected as described by Steffan et al (1984). Uterine discharge was collected from all the experimental and control cows in consistent with the blood sampling.

A sterile glass uterine catheter attached with a twenty (20) $\mathrm{ml}$ of glass syringe with the help of a rubber adapter was used for aspirating uterine fluid by adopting aseptic procedures. A sterilised hollow aluminium cylindrical tube was introduced to the os cervix and used as a protecting device to avoid vaginal contamination. The aspirated uterine content was transferred aseptically into a sterile glass vial. Immediately after collection, uterine sample was used for bacterial count. The bacterial load or the number of surviving bacteria in uterine sample was counted adopting "total plate count technique" as per Malik (1967). One ml of uterine sample was aspirated using a sterile glass pipette and mixed with $9 \mathrm{ml}$ of sterile normal saline solution, so as to attain one 1:10 dilution. Likewise, tenfold serial dilution at $10^{-1}, 10^{-2}, 10^{-3}, 10^{-4}, 10^{-5}$, $10^{-6}, 10^{-7}, 10^{-8}$ and $10^{-9}$ were made in different numbered sterile test tubes. Mueller Hinton agar was used for plate count. The medium was prepared, autoclaved and kept ready for use at molten state at $40-50^{\circ} \mathrm{C}$. One millilitre of diluted uterine sample from each test tube was charged in separate labelled petriplates and molten agar medium of fifteen to twenty $\mathrm{ml}$ was poured into each petriplate. They were mixed thoroughly by rotating in circular fashion to ensure uniform distribution of inoculums. The petriplates were incubated at $37^{\circ} \mathrm{C}$ aerobically for 24 hours and individual colonies were counted with the help of colony counter after end of incubation.

Plates showing isolated and discrete colonies ranging from thirty to five hundred (30 to 500) numbers were counted. The total number of bacteria $(\mathrm{cfu} / \mathrm{ml})$ in uterine sample was calculated as - No. of colonies x dilution rate (Prescott, 2002). The approximate number of bacteria in a suspension was estimated by standard turbidity tubes viz- Brown series (Brown, 1919-20). This method comprised of comparing the opacity of the suspension with that of a series of ten standards tubes containing different dilutions of barium sulphate. Gelatin was added to the suspension as preservative. The opacity was compared with standard opacity tubes with corresponding tables which are supplied by Wellcome Reagents Co. Ltd. Net weight of one E.coli cell $=10^{-6} \mu \mathrm{g}$

$100 \mu \mathrm{g}$ E.coli $=10^{8}$ cells

When the optical density of E.coli is $10^{8}$ cells $/ \mathrm{ml}$, the weight is $100 \mu \mathrm{g}$.

So, the total number of cells used in the treatment protocol for Group -III experimental animals is $10 \times 10^{8}$ cells. (N.B. - the pure attenuated culture of E.coli obtained from HIMEDIA Bio Sciences bearing product code ATCC 25922).

\section{Table 1-.Treatment Protocols}

\begin{tabular}{|c|c|}
\hline $\begin{array}{ll}\text { Control } & \\
\text { Group } \quad(7)\end{array}$ & $\begin{array}{c}\text { Cows in this group were administered with } 50 \mathrm{ml} \text { of normal saline through intra uterine } \\
\text { route. }\end{array}$ \\
\hline Group I (7) & Cows in this group were received $20 \mathrm{ml}$ of fresh colostrum as intra uterine medication. \\
\hline Group II (7) & Intrauterine infusion with $10 \mathrm{ml}$ of non pathogenic E.Coli was given to these cows. \\
\hline
\end{tabular}

\section{RESULTS}

During the investigation, the concentration of predominant bacteria in each uterine sample along with their frequency were evaluated after identification by plate count technique followed by proper staining. Uterine bacterial isolates with their load were displayed in Table- 2 and 3. In the pre treatment stage (Table -2 ), the predominant bacterial flora and their frequency in animals constituted Klebsiella spp (3), Staphylococcus spp (4), E.coli (5), Enterococcus fecalis (1),
Streptococcus spp (5), Proteus spp (1) and Bacillus spp (2). The frequency of appearance of different bacteria in the uterine sample revealed that E.coli and Streptococcus appeared in five cases each, followed by Staphylococcus in four, Klebsiella in three, Bacillus in two and Proteus spp appeared as a solitary isolation. The concentrations of predominant bacterial load $\left(\times 10^{5} \mathrm{cfu} / \mathrm{ml}\right)$ ranged from 0.001 to $8\left(\times 10^{5} \mathrm{cfu} / \mathrm{ml}\right)$. 
Table 2. Uterine predominate bacterial isolates in pre treatment group. Figures within parentheses represent bacterial concentration measured in $\left.\left(\times 10^{5}\right) \mathrm{cfu} / \mathrm{ml}\right]$

\begin{tabular}{ccccc}
\hline $\begin{array}{c}\text { Predominant } \\
\text { Bacteria }\end{array}$ & $\begin{array}{l}\text { Isolated } \\
\text { from } \\
\text { number } \\
\text { of } \\
\text { animals }\end{array}$ & Normal Saline & Colostrum & E.Coli \\
\hline Klebsiella spp & 3 & $(7)$ & $(0.05)$ & $(0.94)$ \\
Staphylococcus spp & 4 & $(0.35) \quad(0.002)$ & $(3.5)$ & $(0.42)$ \\
E.Coli & 5 & $(0.51) \quad(4.2)$ & $(3)$ & $(2.7) \quad(0.51)$ \\
Enterococcus & 1 & $(0.002)$ & - & - \\
fecalis & 5 & $(0.002)$ & $(8) \quad(2.5)$ & $(0.22) \quad(0.001)$ \\
Streptococcus spp & 5 & - & $(0.001)$ & - \\
Proteus spp & 1 & - & $(0.02)$ & $(0.54)$ \\
Bacillus spp & 2 & & & \\
\hline
\end{tabular}

Table 3-Uterine predominate bacterial isolates in post treatment group. Figures within parentheses represent bacterial concentration measured in $\left(\times 10^{5}\right) \mathrm{cfu} / \mathrm{ml}$

\begin{tabular}{ccccc}
\hline Predominant Bacteria & $\begin{array}{c}\text { Isolated from } \\
\text { number of } \\
\text { animals }\end{array}$ & Normal Saline & Colostrum & E.Coli \\
\hline Klebsiella spp & 1 & $(6.5)$ & - & - \\
Staphylococcus spp & 1 & - & $(1)$ & - \\
Streptococcus spp & 3 & - & $(3.4)(0.1)(0.1)$ & (3) (5) (6) (8) (4) (5.3) (2.8) \\
E.Coli & 10 & $(0.001)(2.7)$ & $(0.002)$ & \\
\hline
\end{tabular}

The Klebsiella, Staphylococcus, E.coli and streptococcus spp appeared in all the pre-treatment samples irrespective of drug used which is in agreement with the finding of Prajapati et al (2006). The concentration of pre-treatment bacterial load could be viewed as envisaged from the table- 2 . The bacterial isolates accounted in uterine sample of repeat breeding cows are in agreement with findings of various workers Javed \& Khan (1991), Singh et al (2000), Das (2006) and Gani et al (2008). Besides that all the samples possess bacteria and none of the pre-treatment samples were sterile. Arthur (1970) suggested that bacteria have been isolated even from uterine sample of normal cyclic animal during estrus. Repeat breeding animal may have similar or other type of bacteria but they could cause inflammatory changes during stress condition, when the uterine immunity is compromised. None of the uterine sample showed the presence of Acanobacterium pyogen, Pseudomonas spp and Fusobacterium spp which are known to cause severe inflammatory condition of tubular genital tract with production of 
endotoxins and leucocidal factors as mentioned by Das (2006) and Arthur (1970).

In the post treatment sampling after twenty one days, following different drug treatments revealed inhibition of many bacterial isolates which were identified in the pretreatment period. Klebsiella spp. was found only in normal saline group whereas it was absent in colostrum and E.coli treated group. Similarly Staphylococcus spp. was identified from a single case in colostrum treated group whereas the other two treatment regimen did not reveal their presence. Similar bacterial inhibition against Staphylococcus spp. was marked in normal saline and E.coli, but three cases were positive for Streptococcus spp. in post colostrum treated group. The presence of non pathogenic E.coli was evident in all the treatment groups at post treatment period, indicating either their reinfection or due to its natural presence in the reproductive tract.

Table 4. Analysis of variance of uterine bacterial load following intra-uterine infusion of Normal saline. Colostrum and Non-pathogenic E.coli.

\begin{tabular}{r|ccc|cccccc}
\hline $\begin{array}{r}\text { Treatment } \\
\text { Protocol }\end{array}$ & $\begin{array}{c}\text { Control Group (Normal } \\
\text { Saline) }\end{array}$ & \multicolumn{2}{c|}{$\begin{array}{c}\text { Group-I } \\
\text { (Colostrum) }\end{array}$} & \multicolumn{3}{c}{$\begin{array}{c}\text { Group-II } \\
\text { (Non-pathogenic E.coli) }\end{array}$} \\
\hline $\begin{array}{r}\text { Source of } \\
\text { variation }\end{array}$ & DF & SS & MSS & DF & SS & MSS & DF & SS & MSS \\
\hline Treatments & 1 & 17.96 & $17.96^{\mathrm{NS}}$ & 1 & 12.97 & $12.97^{\mathrm{NS}}$ & 1 & 0.45 & $0.45^{*}$ \\
\hline Error & 12 & 66.29 & 5.52 & 13 & 59.80 & 4.60 & 8 & 0.50 & 0.06
\end{tabular}

* Significant NS = Non significant

\section{DISCUSSION}

The animals in the present study were subjected to an alternative form of therapy as contemporary use of routine antibiotic treatment. Nowadays use of various uterine immunomodulators has gained momentum to treat uterine infections with a view to safe guard the uterine immunity. Use of autologous serum by Das (2006), Levamisole by Behera (2006), E.Coli LPS and Oyster Cell Glycogen by Dhaliwal \& Sidhu (2002) have also been reported and a comparable conception rate was achieved by Coles (1968) who opined that normal saline lavage is as good as any other used normal saline as an uterine lavage in repeat breeding animal and claimed a conception rate of $66.66 \%$. Ahmadi \& Dehghan (2007) evaluated the effect of normal saline and PG $F_{2} \alpha$ in conception rate of repeat breeding cows and suggested uterine lavage could be an effective remedy for cleaning infection of uterus with enhancement of conception rate. The intra uterine infusion of colostrum in the present study is a novel attempt to treat subclinical endometritis in bovines. Colostrum is a potent source of immunoglobulins mostly IgG. Although its use in other routes (orally) has been demonstrated but their efficacy as an uterine lavage has only been established in mares by Sellon \& Long (2013). However, the colostrum and E.coli treated groups have shown promising results in limiting the uterine bacterial components. Due to the prohibiting cost of E.coli LPS, non-pathogenic E.coli was used in this experiment. Previously intrauterine infusion of bacterial endotoxin has reported by Hussain \& Daniel (1992), Rao \& Seshagiri (1998) and Reddy et al (2012). The E.coli cell wall possesses a lipopolysacharide in its cell wall and which is considered to be potent antigen according to Sharma \& Dhaliwal (2010). Singh et al (2000) studied and found that these substances have a chemotactic action to induce proliferation of PMN cells mostly neutrophils and macrophages and these phagocytic cells synthesize cytokines which stimulates both humoral and cellular immunity resulting in elimination of microorganisms.

\section{REFERENCES}

Ahmadi, M. R., Dehghan, S. A. 2007. Evaluation of the treatment of repeat breeder dairy cows with uterine lavage plus $\mathrm{PGF}_{2} \alpha$ with or without cepharin. Turkish J. Vet. Anim. Sci., 31: 125- 129.

Arthur, G.H. 1970. The induction of oestrus in mares by uterine infusion of saline. Vet. Rec., 86: 584-586. 
Azawi, O. I. 2008. Review, Post partum uterine infection in cattle. Animal Reprod. Sci., 105: 187-208.

Behera, A. K. 2006. Response of certain immunomodulation therapy in cyclic non breeding cows. M.V.Sc. Thesis submitted to Orissa University of Agriculture \& Technology, Bhubaneswar.

Coles, E.H. 1968. Veterinary Clinical Pathology. W.B. Saunders Company, Philadelphia and London.

Das, P. 2006. Intrauterine application of autologous serum and its effect on fertility in repeat breeding cows. M.V.Sc. Thesis submitted to Orissa University of Agriculture $\&$ Technology, Bhubaneswar.

Dhaliwal, G.S., Sidhu, S.S. 2002. Immunology of the bovine uterus and immunological strategies to resolve endometritis. Indian J. Anim. Reprod., 23: 105-109.

El-Khadrawy, H. H., Ahmed, W. M., Emtenan, M. Hanafi, M. 2011. Observations on repeat breeding in farm animals with emphasis on its control. J. Reprod. Infert., 2(1): 1-7.

Gani, M. O., Amin, M. M., Alam, M. G. S., Kayesh, M. E. H., Karim, M. R., Samad, M. A., Islam, M. R. 2008. Bacterial flora associated with repeat breeding and uterine infections in dairy cows. Bangl. J. Vet. Med., 6: $79-86$.

Hussain, A.M, Daniel, R.C.W. 1992. Effect of intrauterine infusion of $\mathrm{E}$. coli endotoxin in normal cows by experimental infection with Stre. Agalactiae. Theriogenol. 37: 791-810.

Javed and Khan M.T. 1991. Bacteriological and biohistopathological studies in repeat breeder cows. J. Islamic World Acad. Sci.., 4: 242244.

Malik, B.S. 1967. Laboratory Manual for Bacteriology and Immunology. $1^{\text {st }}$ edn .,British Book Depot., Lucknow.

Prajapati, S. B., Ghodasara, D. J., Prajapati, K. S., Purohit, J. H., Jani, V. R. 2006. Microbiological study of endometritis and its antibiotic spectra in repeat breeder buffaloes. Indian J. Anim. Reprod. 27: 69-71.

Prescott, L. M. 2002. Microbiology. $5^{\text {th }}$ edn., The McGraw-Hill Companies.

Rao, K.S., Seshagiri, V.N. 1998. Effect of intra uterine bacterial infusion induced endometritis on bacterial count, estrus cycle length and progesterone concentration in cross bred cows. Indian J. Anim. Reprod., 19: 29-31.

Reddy, N. C. S., Bramhaiah, K. V., Naidu, K. S. and Kumar, R. V. S. 2012. Effect of uterine lavage on bacterial count and conception rate in repeat breeder crossbred cows. Indian $\mathrm{J}$. Anim. Reprod., 33: 59-61.

Sellon, D. C., Long, M. 2013. Equine infectious diseases. $2^{\text {nd }}$ Edn, ELSEVIER, Australia.

Sharma, S., Dhaliwal G.S. 2010. Escherichia coli lipopolysaccharide induced immunomodulation along with oxytocin administration after mating as a treatment protocol for persistent endometritis in mares. J. Equine Vet. Sci., 30: 259-265.

Singh, H., Dua K., Randhawa, C.S., Singh, P. 2000. Haematology of buffalo around parturition. Indian J. Vet. Med., 20: 83-84.

Singh, J., Sidhu, S.S., Dhaliwal, G.S., Pangaonkar, G.R., Nanda, A.S., Grewal, A.S. 2000. Effectiveness of lipopolysaccharide as an intrauterine immunomodulators in curing bacterial endometritis in repeat breeding crossbred cows. Anim. Reprod. Sci., 59: 159-166.

Steffan, J., Agric, J., Adrimanga, S. 1984. Treatment of metritis with antibiotics or prostaglandin $F_{2 \alpha}$ and influence of ovarian cyclicity in dairy cow. Am. J. Vet. Res., 48: 1090-1094. 